\title{
ENSURING THE RIGHT TO HEALTH OF STAFF OF THE UNITED NATIONS
}

DOl: $10.36740 /$ WLek202009228

\author{
Tetiana L. Syroid, Lina 0. Fomina, Oleksandr A. Havrylenko \\ V.N. KARAZIN KHARKIV NATIONAL UNIVERSITY, KHARKIV, UKRAINE
}

\begin{abstract}
The aim: Of the study is to characterize the internal acts of the United Nations on the regulation of the right to health of its staff.

Materials and methods: Achieving the purpose of the study is ensured due to the analysis of internal acts of the United Nations, doctrinal sources on the issue selected. The methodological basis is a number of special and general methods.

Conclusions: The right to health guaranteed by the International Bill of Human Rights is comprehensive and closely linked to labour human rights. International civil servants of the UN system are not exempt. Thus, within the United Nations, a number of acts have been developed, the provisions of which set out recommendations aimed at reducing possible cases of infection of workers, maintaining their mental health while on quarantine, informing staff about their actions in case of illness, testing workers, etc. However, these acts need to be improved.
\end{abstract}

KEY WORDS: COVID-19, physical state, personnel, international intergovernmental organizations

Wiad Lek. 2020;73(9 p. II):2044-2048

\section{INTRODUCTION}

The human right to health is guaranteed in a number of international human rights treaties and in national law of most states. The Declaration of Alma-Ata, adopted by the International Conference on Primary Health Care in 1978, states that health, as a state of complete physical, mental and social well-being, and not merely the absence of disease or infirmity, is a fundamental human right; and achieving the highest level of health is the world's most important social task, which requires the joint efforts of many social and economic spheres of society. It is worth noting that the observance of the right to health is closely linked to other human rights, particularly, in labour activity, as the effective performance of official duties is possible only if safe working conditions are ensured. This issue becomes significantly relevant during the rapid spread of coronavirus infection COVID-19. In this regard, it is important to pay attention to the issue of observance of the right to health of staff of international intergovernmental organizations, including the United Nations (hereinafter - the UN, the Organization), whose representatives ensure the goals and objectives proclaimed in the UN Charter by holding joint meetings, business trips, reception of persons sent by member states, work with victims of human rights violations, etc. Such activities are potentially threatening the lives and health of such workers in a pandemic. Given this, the topic of the research chosen is relevant.

The issue of international legal regulation of the right to health has been the subject of research in the works of a number of Ukrainian and foreign scientists, including:
Alicia Ely Yamin, Raymond Agius, Steven D. Jamar, Egle Venckienè, A. Abashydze, T. Anakina, M. Baimuratov, M. Buromenskyi, O. Kyivets, N. Khendel and others. Some studies of the legal status of international civil servants were conducted in the works of Gerhard Ullrich, Dag Hammarskjöld, Mona Ali Khalil, Ye. Vasco, P. Fomin, O. Shulipa, and others. However, this topic requires further detailed research.

\section{THE AIM}

The aim of this article is to describe the provisions of the United Nations internal instruments governing the right to health of international civil servants.

\section{MATERIALS AND METHODS}

The study is based on the analysis of international human rights agreements at the universal and regional levels, the provisions of the UN internal acts on ensuring the right to health of its staff, scientific achievements in this area. The methodological basis is a number of special and general methods, in particular, the dialectical method, axiological, formal, and so on. The use of the axiological method allowed us to understand the importance of the right to health of the UN staff in the context of spread of coronavirus infection and its enshrinement in internal acts of the Organization. The formal and legal method used to analyse the provisions on the right to health of the UN staff, including the classification and systematization of mea- 
sures related to the exercise of this right. The application of a set of scientific methods together with the principles, as well as modern scientific approaches made it possible to achieve the purpose of the study.

\section{REVIEW AND DISCUSSION}

The right to health is one of the fundamental human rights and freedoms guaranteed by international law at the universal and regional levels. Thus, the Universal Declaration of Human Rights of 1948 proclaimed the right of everyone to life (Article 3 ) and the standard of living, including food, clothing, housing and medical care and necessary social services, necessary for the maintenance of health and well-being of themselves and their family, and the right to security in case of unemployment, illness, disability, widowhood, old age or other lack of livelihood in circumstances beyond their control (Article 25) [1]. The member states of the International Covenant on Economic, Social and Cultural Rights of 1966 recognize the right of everyone to the highest attainable standard of physical and mental health (Part 1, Article 12) [2]. The Charter of Fundamental Rights of the European Union of 2000 enshrines a rule according to which everyone has the right to preventive treatment and medical care (Article 35) [3]. This right is also enshrined in a number of special international agreements on human rights (Convention on the Rights of the Child of 1989) (Article 24), the UN Convention on the Elimination of All Forms of Discrimination against Women of 1979 (Article 11), and Convention on the Rights of Persons with Disabilities of 2006 (Article 25), etc.).

It should be also emphasized that the right to health is closely linked to and depends on the realization of other human rights guaranteed by the International Bill of $\mathrm{Hu}$ man Rights, including the right to food, housing, employment, education, human dignity, life, etc.

The UN Committee on Economic, Social and Cultural Rights has stated that these and other rights and freedoms are linked to the elements of the right to health. According to the Committee's interpretation, the right to health includes not only the right to prompt and adequate health services, but also to such fundamental preconditions of health as, especially, safe working conditions... (para. 11) [4]. This thesis is supported by the General Comment of the UN Committee on Economic, Social and Cultural Rights № 23 (2016) on the right to fair and favourable working conditions, according to which the fundamental aspect of the right to fair and favourable working conditions is closely linked with other rights, especially with the right to the highest attainable standard of physical and mental health, is the prevention of accidents at work and occupational diseases (para. 25) [5].

Thus, the International Covenant on Economic, Social and Cultural Rights of 1966 stipulates that measures to be taken by State parties to the Covenant for the full realization of the right to health include, inter alia, the improvement of all aspects of environmental and occupational health in industry (para. b, section 2 of Article 12) [2]. The
Charter of Fundamental Rights of the European Union of 2000 also guarantees every employee the right to work in conditions that ensure the protection of his health... (Article 31) [3]. The right to safe and healthy working conditions is also regulated by the European Social Charter (revised) of 1996, the parties to which have undertaken to develop, implement and review regularly the consistent national policies in the field of labour protection, health and safety protection in the workplace, the main purpose of which is to improve labour protection and occupational hygiene, as well as prevention of accidents and injuries resulting from occupational activities...; adopt rules on occupational safety and health; ensure compliance with such rules through measures to monitor compliance with their requirements; to promote the gradual development of occupational hygiene services intended for all employees, the main task of which is to carry out preventive and advisory functions (Article 3) [6].

The UN Committee on Economic, Social and Cultural Rights also noted that the measures provided for in the Covenant of 1966 to improve all aspects of environmental and occupational health in a workplace include, inter alia, measures to prevent accidents at work and occupational diseases; the need to ensure an adequate supply of safe drinking water and basic sanitation services; prevention and reduction of the impact on people of harmful substances, such as radiation and hazardous chemicals, or other harmful environmental conditions that directly or indirectly affect human health. In addition, from a reasonable point of view, occupational health allows to eliminate as much as possible the causes of harmful factors of the working environment [4].

The abovementioned has been confirmed in scientific researches. Thus, Steven D. Jamar notes that the scope of the right to health is much broad and affects many interrelated areas. He notes that Art. 12 of the Covenant on Economic, Social and Cultural Rights obliges States to act to protect and promote health by taking measures in the field of antenatal, neonatal and child health care, "all aspects of environmental and occupational hygiene", disease prevention, treatment and control, and the provision of health services to all become ill... The WHO Global Strategy for "Health for All up to 2000" formulates an approach to primary health care that includes all aspects of nutrition, sanitation, and the environment, occupational safety, health care, education and training of medical staff, and health initiatives. In view of the above, the author concluded that these numerous areas of activity provide a reliable and complete, though not exhaustive, list of areas in which the state must act to fulfil its obligation to ensure the human right to health [7].

Egle Venckiene also drew attention to the fact that the right to health care is one of the fundamental rights without which a person will not be able to enjoy other rights: economic, political and social rights. It includes the right to better physical and mental health. The author notes that the analysis of the provisions of international legal acts show that the right to health care enshrined in 
international treaties and declarations has evolved from a fundamental human value into an independent right, the implementation of which includes an increasing number of measures [8].

Alicia Ely Yamin noted in her work that the right to health includes both health care and health conditions... as well as the right to participate in decisions that affect health... [9].

That is, the right to health is closely interrelated with other rights, including labour rights. International civil servants, who ensure the continuous and efficient functioning of international intergovernmental organizations, including the United Nations, are not an exception, said Dag Hammarskjöld at his lecture at Oxford University.

Thus, the UN has adopted a number of acts that enshrine the rights and responsibilities of its employees, the peculiarities of international civil service, the procedure for protecting their labour rights, as well as regulating issues related to the right to health. The UN Staff Rules and Regulations define the authority of the UN Secretary-General to establish a staff social security plan that includes health regulations. In addition, staff may be invited to participate in the UN Health Insurance Plan on terms to be determined by the Secretary-General (Rule 6.6) [10].

In order to prevent illnesses among employees, which may pose a threat to the health or safety of others, they may from time to time be offered a medical examination by the Director of the United Nations Medical Service or a physician appointed by the Director of the UN Medical Service. Staff members may also be asked to undergo such medical examinations and vaccinations as may be necessary, in the opinion of the Director of the UN Medical Service or a physician appointed by the Director of the UN Medical Service, before or after their return from mission (Rule 4.19). In addition, employees may be asked at any time to submit a medical certificate of their health or to undergo a medical examination at the UN Medical Service or from a medical practitioner designated by the Director of the UN Medical Service. If, in the opinion of the Director of the UN Medical Service, a staff member's health is adversely affected by his or her ability to perform his or her functions, the staff member may be ordered not to go to work and asked to seek the assistance of a qualified practitioner. The employee must comply with any instructions or suggestions in a timely manner. In addition, the employee is obliged to notify immediately the UN doctor of all cases of infectious diseases in their family and of any quarantine affecting their family. In such a case or in the event of any other circumstances that may affect the health of others, the Director of the UN Medical Service decides on possible dismissal of the employee. In this case, the employee receives in full the salary and other benefits due to them during the period of permitted absence from work (Rule 6.2 (f) (g)) [10].

It is worth noting that the issue related to the implementation and protection of the right to health has become significantly relevant in the context of the spread of coronavirus infection COVID-19. In his speech, the
UN Secretary-General said that as the world struggled with COVID-19, the UN was strengthening its readiness and ability to combat the spread of coronavirus among its workforce so that the Organization could continue to fulfil its vital mandate worldwide. He noted that as of March 2020, the UN has 763 health workers working in a variety of health facilities around the world, including at headquarters and field offices that provide UN support services in their vital work [11].

In order to prevent morbidity among staff, the Organization has adopted a number of acts on disease prevention, pandemic procedures (administrative guidelines, Guidelines for emergency support plans, Guidelines for crisis preparedness for staff and families, Alternative working conditions in the context of COVID-19, Guide to the use of masks by UN staff in the context of COVID-19, etc.).

For instance, during the COVID-19 outbreak and its high threat to public health, UN staff was divided into two categories: staff performing critical tasks and staff performing non-critical tasks. Critical staff includes staff assigned critical functions in the event of office closures due to the COVID-19 outbreak to ensure business continuity; non-critical staff - employees who will not be required to work during the closure of the office. When selecting employees as critical staff, the heads of structural units must ensure the following: physical protection of staff and facilities; medical care for staff; maintenance of telecommunication and information technologies; ability to communicate with other organizations and governments; maintenance of engineering networks (electricity, water supply and sewerage), etc. The number of critical staff should be kept to a minimum and include heads of offices, local security management teams, medical staff, security staff, human resources (including consultants), finance, information and communication, and so on. Employees assigned as critical staff should be informed of the consequences of such assignments and that they may be required to remain in quarantine for 14 days in order to limit any possible adverse effects on their part. In order to ensure the continuity of operations, UN offices can be virtually opened during physical closure [12].

In particular, from 16 March 2020 all employees in New York are required to work distant and exercise their duties remotely, unless their physical presence in the building is required to perform basic work in New York and around the world [13].

In addition, in view of the rapid development of the epidemiological situation and the uncertainty regarding the dynamics of COVID-19 transmission, a Meeting Guide was prepared within the UN, in particular, it was recommended to take into account the risk assessment considerations set out in the "Civil Health Protection for mass events: basic considerations" [14].

However, in the event of any meetings, staff members are encouraged to use personal protective equipment to be provided by the Organization based on workplace risk assessments and the UN Directors' Healthcare Risk Reduction Plan through COVID-19. The Staff is also 
encouraged to take all measures deemed reasonable in their places of residence, such as work at home, physical distance, hand hygiene and the use of personal protective equipment, etc. [15].

The Secretary-General and the heads of various units in a number of duty stations around the world have also decided to restrict physical access to UN territory in order to curb the spread of COVID-19, while work continues in virtual mode. In all units in the field of service where such a decision has been made, employees must continue to work distant, except when their physical presence is necessary to perform critical functions. In practice, this means that employees have to perform their duties on a distant basis from an alternative place of work, usually from home. This measure was taken in response to the emergency situation caused by the spread of COVID-19, and is designed to help ensure the sustainability of the Organization at a time when it is extremely important to minimize social contacts. However, at the end of each working week, staff members should mark distant working days in the Umoja system, and when entering information into Umoja, employees should select a new Telecommuting-COVID-19 item from the proposed list [16].

In addition to the tools listed above, the United Nations Office uses a "3-phase system for activating appropriate actions" to manage and coordinate emergency actions in the field of health in the UN system, including COVID-19. This system can be activated in response to disease outbreaks and other health emergencies. Three stages include: stage 1 "Standby"; stage 2 "Active risk mode"; Stage 3 "Emergency mode". During the first phase, all duty stations must be prepared for the fact that such an outbreak may affect their daily activities. Therefore, it is necessary to prepare, review and update constantly health response plans and strategies and to deploy preparedness actions, including information, education on specific diseases and targeted communication. In the mode of active risk mode, which is realized when the outbreak reaches the place of work with some prevalence in the community, it is necessary to implement active measures to reduce risk in the workplace. Measures include the organization of meetings and staff reductions, with a special focus on vulnerable employees, such as employees with weakened immune systems or concurrent illness. The workplace remains open, but risk mitigation measures are being taken, including social distancing and other activities. In the third mode, full implementation of risk management and medical response measures is required due to the large number of cases reported in the host country [17].

If a UN staff member had contact with a person with acute respiratory symptoms such as fever, cough or shortness of breath in the course of their day-to-day work, they should take a number of steps to minimize the risk of infection, whether COVID-19 or any other respiratory disease. These steps may vary for each workplace based on guidelines from UN health services and local health authorities, and UN staff should be familiar with the written protocol of the workplace / office. Thus, an employee who has symptoms of acute respiratory disease (cough, shortness of breath), while at work, must: distance himself from other people at a distance of at least 1 metre (or be in a separate room); cover the nose and mouth with a cloth when coughing or sneezing and wear a surgical mask; return home immediately and stay at home until the respiratory symptoms disappear; consult a physician first by telephone to report symptoms and any travel or possible effects. The healthcare professional will advise staff on any necessary testing or treatment. In addition, information on COVID-19 should be publicly available, including all measures taken in the workplace to ensure safety and health of each employee [18].

The UN also offers COVID-19 testing services to UN staff and staff working in UN permanent and supervisory missions in New York who feel unwell and meet clinical testing criteria. In this situation, the employee should send a letter to osh@un.org to request testing and indicate the employee's name, date of birth, index (if UN), organization (e.g. UNICEF, UNS, Permanent Mission, etc.), full address with postal code, contact phone. Testing is not available to dependents [19].

It is worth noting that the restriction of social activity, the duration of duties using information and communication technologies, while at home, other radical changes in lifestyle through the introduction of quarantine measures can affect the psychological health of individuals. With this in mind, the UN Guidelines for the Protection of Mental Health during COVID-19 set out a number of recommendations aimed at maintaining their well-being during this period. Among them: provision of basic needs (sufficient rest time, observance of a balanced diet, physical activity, etc.); minimization of factors that affect mental health negatively (reduction of smoking, alcohol consumption, obtaining reliable information about the situation with COVID-19 in verified sources to prevent misinformation); keeping in touch (communicating with friends, colleagues to reduce feelings of loneliness); defining clear boundaries between personal life and work (compliance with the work regime, taking a break), etc. [20].

Raymond Agius in his paper on COVID-19 and occupational health, also emphasizes that traditional occupational health measures, such as segregation, ventilation, personal protective equipment, etc., must be comprehensive to prevent the virus from recurring. Employees returning to work should be screened for symptoms and contact history.

\section{CONCLUSIONS}

Thus, based on the abovementioned, it can be concluded that the right to health guaranteed by the International Charter of Human Rights is comprehensive and closely linked to labour human rights, in particular the creation of safe working conditions, prevention of occupational diseases and injuries. International civil servants of the UN system are not exempt, as they ensure the continuous functioning of the Organization and the achievement of its goals and the ideals it aspires. UN staff exercise a wide 
range of responsibilities around the world, accompanied by a significant number of contacts with other colleagues, government officials, and so on. This situation has become threatening in light of the active spread of COVID-19. Thus, the UN has adopted a set of internal acts that regulates the legal status of employees in detail, including issues related to their health. However, in view of the expansion of the pandemic, the Organization has developed a number of acts, the provisions of which set out recommendations aimed at reducing possible cases of infection of workers, maintaining their mental health while on quarantine, informing staff about their actions in case of symptoms of acute respiratory diseases and regulates the issue of the continuous functioning of the UN during this period. In addition, the UN has created conditions for testing workers for COVID-19, provided that they meet clinical criteria, however, such testing is not available to members of their families, that may significantly increase the incidence among staff.

\section{REFERENCES}

1. Universal Declaration of Human Rights. 2020. https://www.un.org/en/ universal-declaration-human-rights/

2. International Covenant on Economic, Social and Cultural Rights. 2020. https://www.ohchr.org/en/professionalinterest/pages/cescr.aspx

3. Charter of fundamental rights of the European Union (2000/C 364/01). https://www.europarl.europa.eu/charter/pdf/text_en.pdf

4. Committee on economic, social and cultural rights General Comment No. 14 (2000) (The right to the highest attainable standard of health (article 12 of the International Covenant on Economic, Social and Cultural Rights)) E/C.12/2000/4. https://undocs.org/E/C.12/2000/4

5. General comment No. 23 (2016) on the right to just and favourable conditions of work (article 7 of the International Covenant on Economic, Social and Cultural Rights)) E/C.12/GC/23. https://undocs.org/E/C.12/ $\mathrm{GC} / 23$

6. European Social Charter (revised). 2020. https://www.coe.int/en/web/ conventions/full-list/-/conventions/treaty/163

7. Steven D.J.The international human right to health. Southern University law review. Southern University and A \& M College. School of Law. 1994. 22(1):1-68.

8. Venckiene E. Relationship between the right to dignity and the right to healthcare. International Journal of Arts and Commerce. 2014;3(5): 166-176.

9. Yamin A.E. The Right to Health under International Law and Its Relevance to the United States. Am J Public Health.2005. 95(7):1156-1161. doi: 10.2105/AJPH.2004.055111.

10. Staff Rules and Staff Regulations of the United NationsST/SGB/2014/1. https://undocs.org/ST/SGB/2014/1

11. «I'm behind you» Secretary-General tells UN health workers fighting COVID-19 by the Department of global communications. https://www.un.org/en/un-coronavirus-communicationsteam/\%E2\%80\%9Ci\%E2\%80\%99m-behind-you\%E2\%80\%9D-unchief-tells-health-workers-they-fight-covid

12. Administrative Guidelines for Offices on the Novel Coronavirus (COVID-19) pandemic. Framework for the management of staff members in United Nations Common System Headquarters and Field Duty Stations (CEB Human Resources Network Version 4.014 April 2020). https://www.un.org/sites/un2.un.org/files/covid_032_ administrative_guidelines_for_offices_on_the_novel_coronavirus_ covid-19_outbreak_version_4.0_ra_e.pdf

13. United Nations Headquarters - Emergency Information. from:http:// emergency.un.org/

14. UN Meetings in the Context of COVID-19. Guidance for organizers holding meetings during the COVID-19 outbreak. 2020. https://hr.un. org/sites/hr.un.org/files/Global\%20Guidance\%20for\%20UN\%20 Meetings\%20for\%20COVID-19_10Mar\%20_0.pdf

15. Guidance on the use of facemasks by un personnel in context of COVID-19. 2020. https://www.un.org/sites/un2.un.org/files/use_of_ facemasks_by_un_personnel.pdf

16. Al'ternativnyy rezhim raboty v kontekste COVID-19 (Alternative working arrangements in the context of COVID-19). 2020. https://www.un.org/ sites/un2.un.org/files/covid_003_alternate_working_arrangements_ in_the_context_of_covid-19_ra_r.pdf

17. United Nations medical directors COVID-19 pandemic guidelines (March 31, 2020). https://www.un.org/sites/un2.un.org/files/coronavirus_ unmdpandemicguide_2020-03-31_final.pdf

18. Management of UN personnel with acute respiratory illness/symptoms in the workplace (6 March 2020). https://hr.un.org/sites/hr.un.org/files/ Coronavirus_SuspectCaseGuideNonMedical_DHMOSHPH_0.pdf

19. COVID-19 Testing in the New York area. https://www.un.org/en/ coronavirus/covid-19-testing

20. Advice for UN staff for protecting your mental health during COVID-19 (23 MARCH 2020). https://www.un.org/sites/un2.un.org/files/ staying_healthy_at_home-covid_19_final.pdf

21. Raymond A. Covid-19 and Health at Work. Occupational Medicine, kqaa075. 2020. doi.org/10.1093/occmed/kqaa075.

\section{ORCID and contributionship:}

Tetiana L. Syroid: 0000-0002-8165-4078 A, B, D, F

Lina O. Fomina: 0000-0002-8756-4006 A, B, D, F

Oleksandr A. Havrylenko: 0000-0001-5554-4919 ${ }^{A, E}$

\section{Conflict of interest:}

The Authors declare no conflict of interest.

\section{CORRESPONDING AUTHOR}

\section{Tetiana L. Syroid}

V. N. Karazin Kharkiv National University

4 Svobody Sq., 61022 Kharkiv, Ukraine

tel: +380677042283

e-mail:syroid02@gmail.com

Received: 04.06 .2020

Accepted: 10.08 .2020

A - Work concept and design, B - Data collection and analysis, C - Responsibility for statistical analysis,

D-Writing the article, $\mathbf{E}-$ Critical review, $\mathbf{F}-$ Final approval of the article 